in vivo $32: 1541-1550(2018)$

doi:10.21873/invivo.11412

\title{
Radiological Features of Programmed Cell Death-Ligand 2-positive Lung Adenocarcinoma: A Single-institution Retrospective Study
}

\author{
KAZUKI TAKADA ${ }^{1,2}$, GOUJI TOYOKAWA ${ }^{1}$, KOICHI AZUMA ${ }^{3}$, SHINKICHI TAKAMORI ${ }^{1}$, TOMOKO JOGO ${ }^{1,4}$, \\ FUMIHIKO HIRAI $^{1}$, TETSUZO TAGAWA ${ }^{1}$, AKIHIKO KAWAHARA ${ }^{5}$, JUN AKIBA ${ }^{5}$, ISAMU OKAMOTO ${ }^{6}$, \\ YOICHI NAKANISHI ${ }^{6}$, YOSHINAO ODA ${ }^{4}$, TOMOAKI HOSHINO ${ }^{3}$ and YOSHIHIKO MAEHARA ${ }^{1}$ \\ ${ }^{1}$ Department of Surgery and Science, ${ }^{4}$ Department of Anatomic Pathology, and \\ ${ }^{6}$ Research Institute for Disease of the Chest, Graduate School of Medical Sciences, Kyushu University, Fukuoka, Japan; \\ ${ }^{2}$ Department of Thoracic Oncology, National Kyushu Cancer Center, Fukuoka, Japan; \\ ${ }^{3}$ Division of Respirology, Neurology, and Rheumatology, Department of Internal Medicine, and \\ ${ }^{5}$ Department of Diagnostic Pathology, Kurume University School of Medicine, Kurume, Japan
}

\begin{abstract}
Aim: Programmed cell death-ligand 1 and 2 (PD-L1 and PD-L2) are ligands of the programmed cell death1 (PD1) receptor. PDI/PD-L1 inhibitors have shown clinical efficacy in non-small cell lung cancer (NSCLC). However, relatively little is known about the expression of PD-L2, or its association with the clinicopathological features of NSCLC. Here, the radiological features of PD-L2-positive lung adenocarcinoma were evaluated. Materials and Methods: PDL1 and PD-L2 expression were evaluated by immunohistochemical staining of surgically-resected specimens from 393 patients with primary lung adenocarcinoma who underwent preoperative thin-section computed tomography (CT), 222 of whom also underwent ${ }^{18} \mathrm{~F}$-fluorodeoxyglucose positron-emission tomography/CT $\quad\left({ }^{18} \mathrm{~F}-\mathrm{FDG}-\mathrm{PET} / \mathrm{CT}\right)$. Results: Among the 393 specimens, 132 (33.6\%) and 266 $(67.7 \%)$ were positive for PD-L1 and PD-L2 expression, respectively. Multivariate analysis showed that the absence of surrounding ground glass opacity and the presence of air bronchogram were significantly associated with PD-L2 expression; however, there was no significant association between PD-L2 expression and the consolidation/tumor ratio. In $222{ }^{18}$ F-FDG-PET/CT, the maximum standardized uptake value was significantly higher in patients with PD-L2-positive
\end{abstract}

This article is freely accessible online.

Correspondence to: Kazuki Takada, MD, Ph.D., Department of Thoracic Oncology, National Kyushu Cancer Center, 3-1-1 Notame, Minami-ku, Fukuoka 811-1395, Japan. Tel: +81 925413231, Fax: +81925514585, e-mail:k_takada@surg2.med.kyushu-u.ac.jp

Key Words: CT, PD-L2, lung adenocarcinoma. compared to those with PD-L2-negative tumors. Conclusion: $P D$-L2-positive lung adenocarcinomas are less radiologically malignant and invasive than their PD-L1-positive counterparts.

Immunotherapeutic targeting of the T-cell-inhibitory protein programmed cell death-1 (PD1) and of its ligand programmed cell death-ligand 1 (PD-L1) has garnered a great deal of attention in recent years as a novel treatment option for nonsmall cell lung cancer (NSCLC). Indeed, anti-PD1/PD-L1 immunotherapy has been shown to significantly prolong the survival of patients with NSCLC compared to conventional standard chemotherapy in many clinical trials (1-6). To date, immunohistochemical (IHC) detection of tumor PD-L1 expression has proven to be the most useful predictive biomarker of response to PD1/PD-L1 immunotherapy. However, some patients with PD-L1-negative tumors do respond to such therapy, suggesting that additional biomarkers will be necessary to accurately predict the response to therapy targeting the PD1 checkpoint $(7,8)$.

Programmed cell death-ligand 2 (PD-L2) is the second identified ligand for PD-1 (9). Although PD-L1 appears to be the main ligand, its binding affinity for PD1 is 2- to 6-fold lower than that of PD-L2 (10). However, there have been relatively few reports about the clinical significance of PD-L2 expression in NSCLC, and its precise roles in the human tumor microenvironment and its utility as a prognostic or predictive marker have not yet been established (11-15). We recently investigated the clinical utility of PD-L2 expression in NSCLC and identified a significant association between its expression in primary lung adenocarcinoma and patient survival (unpublished observation). Here, we extended this study to investigate the clinical features of PD-L2positive lung adenocarcinoma in more detail. 
Recently, we identified several associations between PDL1 expression and clinical features in 394 patients with primary lung adenocarcinomas; these included radiological characteristics on computed tomography (CT) (16) and metabolic characteristics by ${ }^{18} \mathrm{~F}$-fluorodeoxyglucose positron-emission tomography/CT $\left({ }^{18} \mathrm{~F}-\mathrm{FDG} \mathrm{PET} / \mathrm{CT}\right)(17$, 18). In the present study, we analyzed the same features for the same patient cohort in the context of tumor PD-L2 expression. The results allow for comparison and clarification of the clinical significance of PD-L2 and PD$\mathrm{L} 1$ expression in patients with primary lung adenocarcinoma.

\section{Materials and Methods}

Patients and samples. This study retrospectively examined patients who underwent surgical resection of primary lung adenocarcinoma between January 2003 and December 2012 at the Department of Surgery and Science, Graduate School of Medical Sciences, Kyushu University. We previously analyzed the relationship between PD-L1 expression and clinical features in 394 patients who had undergone preoperative thin-section CT at our Institution (16). Among those, 393 patients whose formalin-fixed and paraffin-embedded tumor tissue sections were available for IHC of PD-L2 were enrolled in this study. The clinicopathological features, including age at surgery, sex, smoking history, pathologic tumor-node-metastasis stage (seventh edition of the American Joint Committee on Cancer lung cancer staging system) (19), pleural and lymphovascular invasion, histological subtype (World Health Organization Classification 2015) (20), and epidermal growth factor receptor (EGFR) mutation status were examined. EGFR status had been determined in 230 specimens of tumor tissue using the peptide nucleic acid-locked nucleic acid polymerase chain reaction clamp method (Mitsubishi Chemical Medience, Tokyo, Japan) (21). Clinical information was obtained from medical records. This study was approved by our Institutional Review Board (Kyushu University, IRB No. 29-261).

Chest CT. Chest CT was performed in the supine position during inspiratory breath-hold using various multi-detector row scanners: Aquilion 4, Aquilion 64, Aquilion ONE, Aquilion ONE Vision (all Toshiba), SOMATOM Plus4 Volume Zoom (Siemens Medical Solutions, Erlangen, Germany), Brilliance CT, and Brilliance iCT (both Philips Healthcare, Amsterdam, the Netherlands). The imaging parameters for thin-section $\mathrm{CT}$ were as follows: tube voltage $120 \mathrm{kVp}$, tube current 100-500 mA, scan field of view 320-360 mm, and slice thickness $2 \mathrm{~mm}$. Real exposure control (Toshiba, Tokyo, Japan) or automatic exposure control (Siemens and Phillips) was included in each study. All of the CT data sets were transferred to a Picture Archiving and Communication System, which was accessible by the workstations (Volume Analyzer Synapse-Vincent; Fujifilm, Tokyo, Japan) using a specialized application for lung CTs. The diameter of consolidation in each tumor (C) and the diameter of the whole tumor (T), including ground glass opacity (GGO), were measured manually with axial 2-dimensional CT data on 2-mm slice sections and the $\mathrm{C} / \mathrm{T}$ ratio was calculated. Three thoracic oncologists (KT, GT, and ST) evaluated all of the CT images, and disagreements were resolved by consensus.

${ }^{18} \mathrm{~F}$-FDG PET/CT. ${ }^{18} \mathrm{~F}-\mathrm{FDG}$ PET/CT scanning was performed using SECAT EXACT HR+, Biograph mCT (both Siemens), and
Discovery STElite16 (GE) scanners. The maximum standardized uptake value (SUVmax) of the tumor was calculated.

Immunohistochemical analysis. PD-L1 and PD-L2 expression in formalin-fixed, paraffin-embedded tumor sections was performed by IHC using primary antibodies against PD-L1 (1:100 dilution, rabbit monoclonal, clone SP142; Spring Bioscience, Ventana, Tucson, AZ, USA) and PD-L2 (1:200 dilution, mouse monoclonal, clone 176611; R\&D Systems, Minneapolis, MN, USA). For PD-L1, staining was performed as previously described (16-18, 22-31). For PD-L2, 4- $\mu$ m-thick sections were mounted on glass slides and stained using a B Bond-III autostainer (Leica Microsystems, Bannockburn, IL, USA). Briefly, sections were treated with proteinase K (Agilent/Dako, Carpinteria, CA, USA) for $5 \mathrm{~min}$, and incubated with the antibody for $30 \mathrm{~min}$. The automated staining setup used a Bond Polymer Refine Detection system (Leica Microsystems) with a horseradish peroxidase-coupled polymer secondary antibody and 3,3' diaminobenzidine (DAB) as the chromogen. The slides were visualized using DAB.

Carcinoma cells showing membranous staining for PD-L1 or PD-L2 were classified as positive, and the percentage of positive cells was calculated from the whole stained section. Sections with less than $1 \%$ tumor membrane staining were considered negative in this study. IHC images were evaluated independently by three investigators (KT, ST, and TJ) who were blinded to the patient clinical data. Disagreements were resolved by consensus.

Statistical analysis. Univariate and multivariate analyses of the relationship of PD-L1 and PD-L2 expression with CT features (convergence, surrounding GGO, air bronchogram, notching, pleural indentation, spiculation, and cavitation) were performed by logistic regression analysis with a backward elimination method. Associations between PD-L1/PD-L2 expression, the C/T ratio and clinicopathological factors were examined by Fisher's exact test. Associations between PD-L1/PD-L2 expression and SUVmax in preoperative ${ }^{18} \mathrm{~F}-\mathrm{FDG}$ PET/CT were evaluated using Student's $t$-test. All statistical analyses were performed using JMP Statistical Discovery software (version 11.0; SAS Institute, Cary, NC, USA). A value of $p<0.05$ was considered statistically significant.

\section{Results}

Patient characteristics. Patient characteristics are shown in Table I. The median age of the 393 patients was 69 years (range $=29-85$ years); $196(49.9 \%)$ were male and 201 (51.1\%) had never smoked. The EGFR mutation status was available for 230 patients. Of these, 119 (51.7\%) and 111 (48.3\%) expressed wild-type and mutant EGFR, respectively.

PD-L1 and PD-L2 positivity was defined as positive membranous staining of $\geq 1 \%$ of cancer cells on IHC staining of lung adenocarcinoma sections (Figure 1). Of the 393 patients, $132(33.6 \%)$ and $266(67.7 \%)$ were positive for PD-L1 and PD-L2 expression, respectively. PD-L1 and PD-L2 were co-expressed by 98 (24.9\%) patients. Figure 2 shows representative images of the $\mathrm{CT}$ features investigated: convergence, surrounding GGO, air bronchogram, notching, pleural indentation, spiculation, and cavitation. These features were observed in 264 
Table I. Patient clinicopathological characteristics $(N=393)$.

\begin{tabular}{|c|c|}
\hline Factors & Value \\
\hline \multicolumn{2}{|l|}{ Age, years } \\
\hline Median (range) & $69(29-85)$ \\
\hline \multicolumn{2}{|l|}{ Gender, $\mathrm{n}$} \\
\hline Male & 196 \\
\hline Female & 197 \\
\hline \multicolumn{2}{|l|}{ Smoking status, $\mathrm{n}$} \\
\hline Never-smoker & 201 \\
\hline Smoker & 192 \\
\hline \multicolumn{2}{|l|}{ RadiologicaI tumor diameter, $\mathrm{cm}$} \\
\hline Median (range) & $2.1(0.3-10.7)$ \\
\hline \multicolumn{2}{|l|}{ Pathological stage, $n$} \\
\hline IA & 213 \\
\hline IB & 73 \\
\hline IIA & 33 \\
\hline IIB & 28 \\
\hline IIIA & 36 \\
\hline IIIB & 5 \\
\hline IV & 5 \\
\hline \multicolumn{2}{|l|}{ Pleural invasion, $\mathrm{n}^{\mathrm{a}}$} \\
\hline No & 305 \\
\hline Yes & 87 \\
\hline \multicolumn{2}{|l|}{ Lymphatic invasion, $\mathrm{n}$} \\
\hline No & 337 \\
\hline Yes & 56 \\
\hline \multicolumn{2}{|l|}{ Vascular invasion, $\mathrm{n}$} \\
\hline No & 279 \\
\hline Yes & 114 \\
\hline \multicolumn{2}{|l|}{ Histological subtype, $\mathrm{n}$} \\
\hline AAH/AIS/MIA & 39 \\
\hline Lepidic-predominant & 24 \\
\hline Papillary-predominant & 290 \\
\hline Acinar-predominant & 6 \\
\hline Micropapillary-predominant & 1 \\
\hline Solid-predominant & 26 \\
\hline Variant & 7 \\
\hline \multicolumn{2}{|l|}{ EGFR, na } \\
\hline Wild-type & 119 \\
\hline Mutant & 111 \\
\hline \multicolumn{2}{|l|}{ PD-L1, n } \\
\hline Negative & 261 \\
\hline Positive & 132 \\
\hline \multicolumn{2}{|l|}{ PD-L2, n } \\
\hline Negative & 127 \\
\hline Positive & 266 \\
\hline \multicolumn{2}{|l|}{ PD-L1/PD-L2, n } \\
\hline Co-expression & 98 \\
\hline Other ${ }^{b}$ & 295 \\
\hline
\end{tabular}

EGFR: Epidermal growth factor receptor, PD-L1: programmed cell death-ligand 1, PD-L2: programmed cell death-ligand 2, AAH: atypical adenomatous hyperplasia, AIS: adenocarcinoma in situ, MIA: minimally

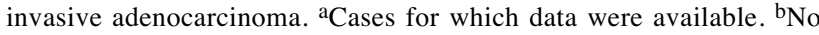
expression or single protein expression.

$(67.2 \%), 189(48.1 \%), 312(79.4 \%), 142(36.1 \%), 311$ $(79.1 \%), 178(45.3 \%)$, and $73(18.6 \%)$, respectively, of the 393 patients (Tables II and III).
Association between tumor PD-L2 expression and CT features. Table II shows the relationship between PD-L2 expression and CT features. Univariate analysis identified significant associations between PD-L2 expression and the presence of convergence, air bronchogram, and spiculation, and the absence of surrounding GGO. In multivariate analysis, the presence of air bronchogram and the absence of surrounding GGO were significantly associated with PD-L2 expression (Table II).

Table IV shows the PD-L2 expression status stratified by the $\mathrm{C} / \mathrm{T}$ ratio. Positive $\mathrm{PD}-\mathrm{L} 2$ expression was observed in $8.3 \%, 6.0 \%, 12.0 \%$, and $73.7 \%$ of tumors with $\mathrm{C} / \mathrm{T}$ ratios of $0,0.1$-q0 $0.25,0.26-0.5$, and $\geq 0.51$, respectively ( $p=0.3188)$.

Association between tumor PD-L2 expression and metabolic activity on ${ }^{18} F-F D G P E T / C T$. the relationship between tumor PD-L2 expression and metabolic characteristics of primary lung adenocarcinoma was evaluated in the 222 patients for whom ${ }^{18}$ F-FDG PET/CT data were available. The average $\mathrm{SUV}_{\text {max }}$ of the patients with positive PD-L2 expression was significantly higher than that of PD-L2-negative patients [6.33 (range=0-30.4) and 3.92 (range=0-14.9), respectively; $p=0.0009]$ (Figure 3A).

Association between tumor PD-L1/PD-L2 co-expression and features on $C T$ and ${ }^{18} F-F D G P E T / C T$. We next evaluated the relationship between radiological and metabolic features and PD-L1/PD-L2 co-expression in primary lung adenocarcinoma. Univariate analysis revealed that PD-L1/PD-L2 co-expression was significantly associated with the presence of convergence, notching, spiculation, and cavitation and the absence of surrounding GGO. In multivariate analysis, the presence of convergence and cavitation and the absence of surrounding GGO remained significantly associated with PD-L1/PD-L2 co-expression (Table III). Positive PD-L1/PD-L2 coexpression was observed in $3.1 \%, 3.1 \%, 6.1 \%$, and $87.7 \%$ of tumors with $\mathrm{C} / \mathrm{T}$ ratios of $0,0.1-0.25,0.26-0.5$, and $\geq 0.51$, respectively ( $p=0.0006$, Table $\mathrm{V})$. With regard to ${ }^{18} \mathrm{~F}-\mathrm{FDG}$ $\mathrm{PET} / \mathrm{CT}$, the SUVmax was significantly higher in patients with PD-L1/PD-L2 co-expression than all other patients $(p<0.0001$, Figure 3B).

Association between tumor PD-L1/PD-L2 expression and patient clinicopathological features. Finally, we examined the association between PD-L1 and/or PD-L2 expression and clinicopathological factors in our patient cohort (Table VI). PD-L2 expression was significantly higher in non-smokers than in smokers. Unlike PD-L1, however, PD-L2 expression was not significantly associated with EGFR status. Moreover, PD-L1 expression tended to be more significantly associated than PD-L2 expression with pathologically invasive features such as pleural invasion, vascular invasion, and histological subtype. 
a

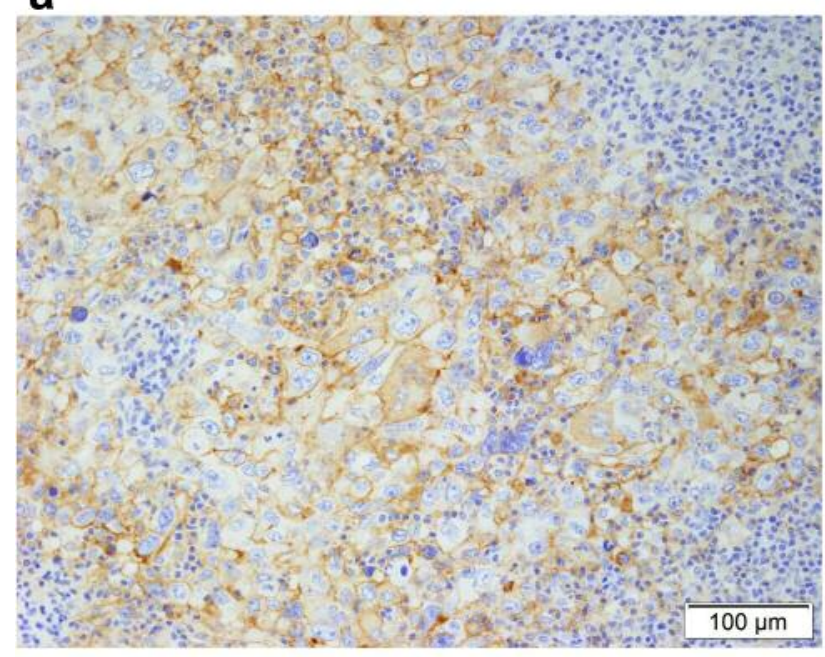

b

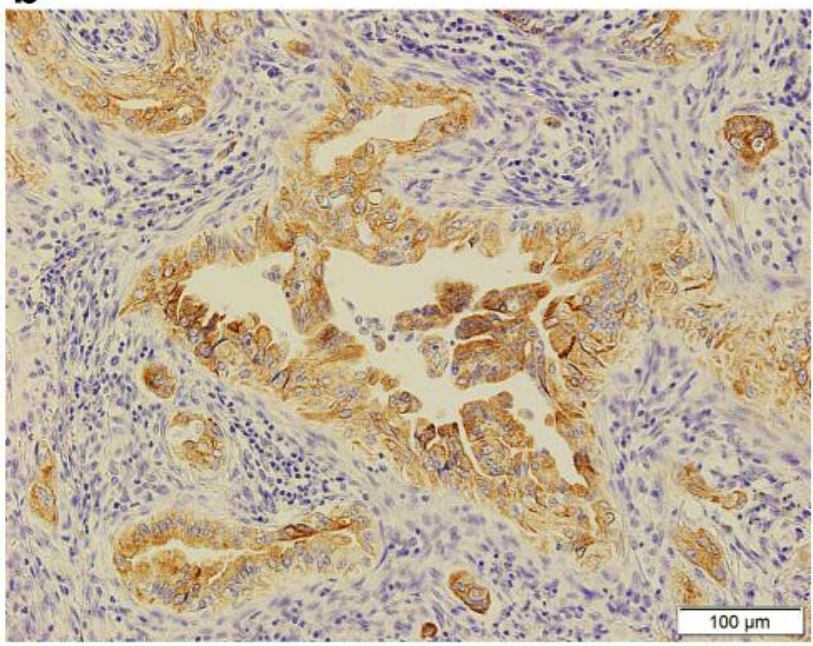

Figure 1. Representative images of positive membranous immunohistochemical staining for programmed cell death-ligand 1 (PD-L1) (A) and programmed cell death-ligand $2(P D-L 2)(B)$ in surgically resected specimens from patients with primary lung adenocarcinoma. Scale bar: 100 um.

\section{Discussion}

In this study, we examined the relationship between PD-L2 expression and radiological features of primary lung adenocarcinoma. We previously reported that PD-L1 expression was significantly associated with the absence of surrounding GGO and air bronchogram and the presence of convergence and cavitation in lung adenocarcinoma (16). In the present study, however, we found that the absence of surrounding GGO and the presence of air bronchogram were significantly associated with PD-L2 expression in the same patient cohort and tumor samples. Convergence is considered to reflect tumor fibrosis, whereas cavitation is thought to be associated with tumor necrosis, which is observed when rapid tumor growth exceeds the available blood supply (16). Therefore, convergence and cavitation, which were significantly associated with tumor expression of PD-L1 but not PD-L2, are thought to be associated with tumor malignancy in NSCLC. Air bronchogram is a radiological finding in which an air-filled bronchus is surrounded by fluid-filled airspaces; notably, it is not found in invasive adenocarcinoma where alveolar septa, bronchi, and vasculature are destroyed (16).

Air bronchogram on CT scans of lung cancer patients has been the subject of several reports and was shown to be a significant predictor of pathological N0 status (32-35). Moreover, in studies examining the associations between air bronchogram, PD-L1, and driver oncogenes in patients with lung cancer, PD-L1 expression was significantly associated with the absence of air bronchogram (16), whereas EGFR mutation was significantly associated with the presence of air bronchogram $(34,35)$, and anaplastic lymphoma kinase rearrangement was unrelated to air bronchogram on CT (34). These findings suggest that the absence of air bronchogram is associated with malignancy and invasive features in lung cancer. Although a mechanistic link between air bronchogram and PD-L2 expression remains to be determined, our finding of a significant association between the presence of air bronchogram and PD-L2 expression suggests that PD-L2-positive lung adenocarcinoma may be less malignant and invasive than PD-L1-positive tumor. Moreover, we found a significant association between the $\mathrm{C} / \mathrm{T}$ ratio and PD-L1 expression, as previously reported (23), but not PD-L2 expression. The predominance of GGO suggests noninvasive of the tumor, as the Japan Clinical Oncology Group 0201 study defined the tumor with a C/T ratio $\leq 0.25$ on thin-section $\mathrm{CT}$ as radiologically noninvasive lung adenocarcinoma, since such tumors correspond well to pathologically noninvasive adenocarcinomas (36). Actually, in this study, PD-L1 expression tended to be more associated with pathologically invasive features than PD-L2 expression. From these findings, PD-L2 expression may not be as closely associated with tumor invasiveness as PD-L1 expression in primary lung adenocarcinoma.

We evaluated the metabolic characteristics of primary lung adenocarcinoma in 222 patients for whom preoperative ${ }^{18} \mathrm{~F}-\mathrm{FDG} \mathrm{PET} / \mathrm{CT}$ data were available, and found that SUVmax was significantly higher in patients with PD-L2positive compared with those with PD-L2-negative tumors. We previously showed a similar association for metabolic activity and PD-L1-positive lung adenocarcinoma $(17,18)$. A 
A

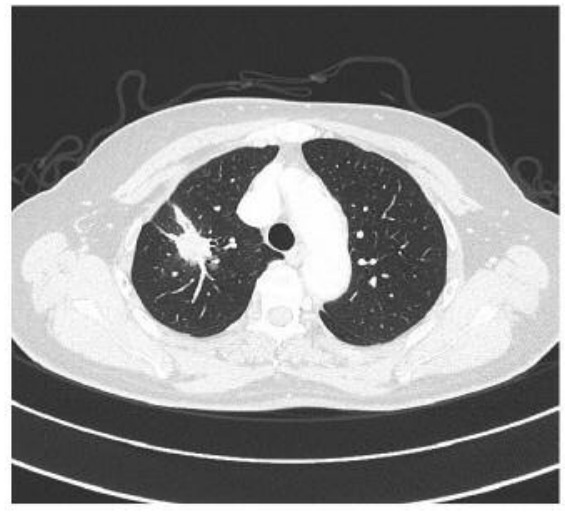

C

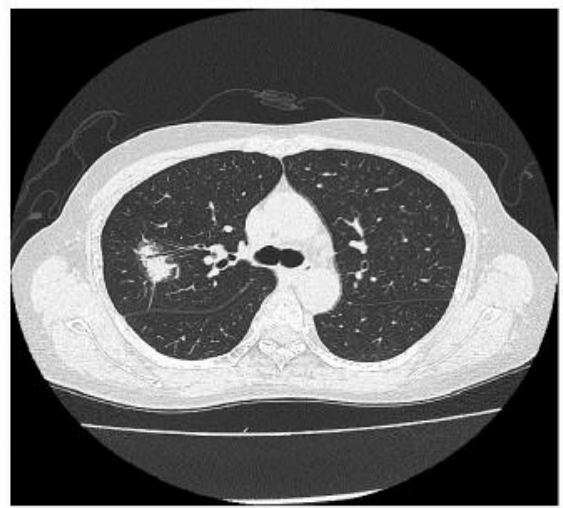

E

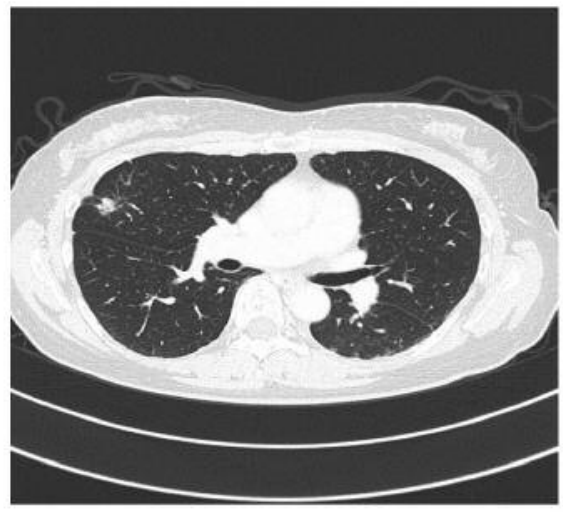

G

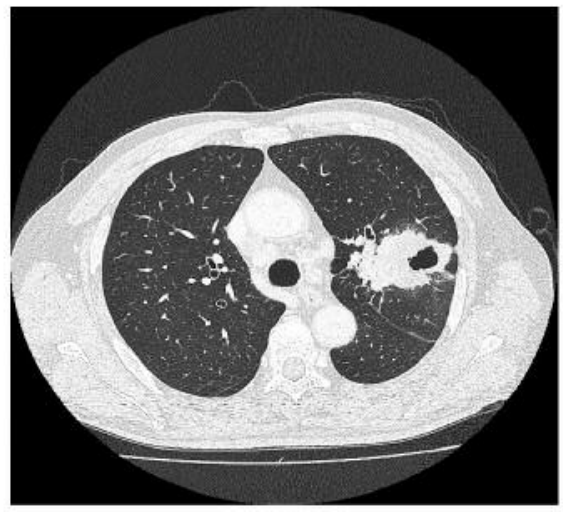

B

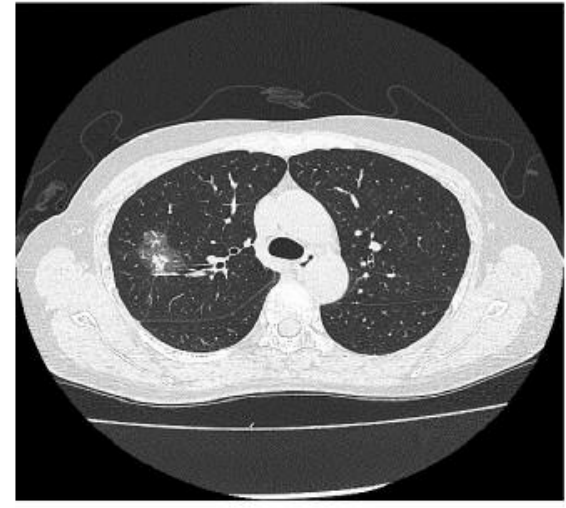

D

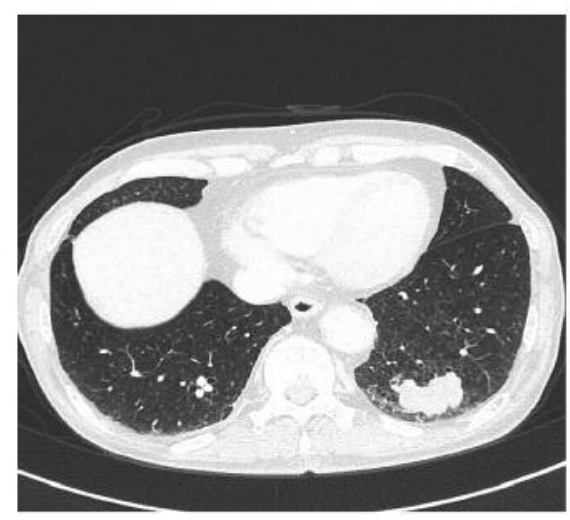

F

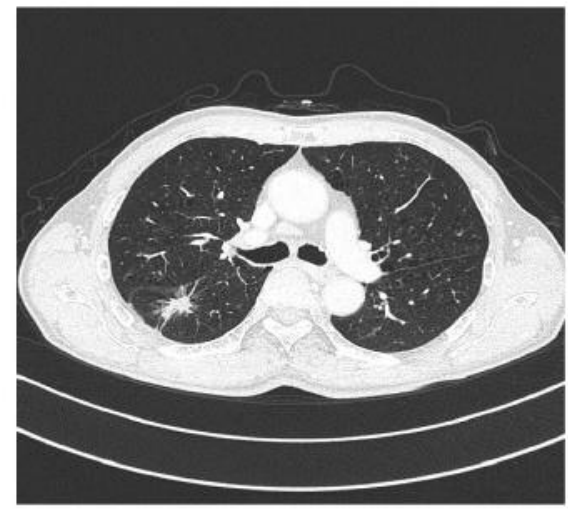

Figure 2. Representative computed tomographic images of lung adenocarcinoma patients showing typical features of Convergence (A), surrounding ground glass opacity $(B)$, air bronchogram $(C)$, notching $(D)$, pleural indentation $(E)$, spiculation $(F)$, and cavitation $(G)$. 
Table II. Univariate and multivariate analysis of the associations between programmed cell death-ligand 2 (PD-L2) expression and computed tomographic (CT) features.

\begin{tabular}{|c|c|c|c|c|c|c|c|c|c|c|}
\hline \multirow[t]{2}{*}{ CT feature } & & \multirow[t]{2}{*}{$\mathrm{N}(\%)$} & \multicolumn{2}{|c|}{ PD-L2, N (\%) } & \multicolumn{3}{|c|}{ Univariate analysis } & \multicolumn{3}{|c|}{ Multivariate analysis } \\
\hline & & & Negative & Positive & OR & $95 \% \mathrm{CI}$ & $p$-Value & OR & $95 \% \mathrm{CI}$ & $p$-Value \\
\hline \multirow[t]{2}{*}{ Convergence } & - & $129(32.8)$ & $54(42.5)$ & $75(28.2)$ & 1.00 & & & & & \\
\hline & + & $264(67.2)$ & $73(57.5)$ & $191(71.8)$ & 1.88 & $1.21-2.93$ & 0.0051 & & & \\
\hline \multirow[t]{2}{*}{ Surrounding GGO } & - & $204(51.9)$ & $54(42.5)$ & $150(56.4)$ & 1.00 & & & 1.00 & & \\
\hline & + & $189(48.1)$ & $73(57.5)$ & $116(43.6)$ & 0.57 & $0.37-0.88$ & 0.0100 & 0.52 & $0.33-0.80$ & 0.0032 \\
\hline \multirow[t]{2}{*}{ Air bronchogram } & - & 81 (20.6) & $34(26.8)$ & 47 (17.7) & 1.00 & & & 1.00 & & \\
\hline & + & $312(79.4)$ & $93(73.2)$ & $219(82.3)$ & 1.70 & $1.03-2.81$ & 0.0400 & 1.95 & $1.16-3.29$ & 0.0121 \\
\hline \multirow[t]{2}{*}{ Notching } & - & $251(63.9)$ & $86(67.7)$ & $165(62.0)$ & 1.00 & & & & & \\
\hline & + & $142(36.1)$ & $41(32.3)$ & $101(38.0)$ & 1.28 & $0.82-2.02$ & 0.2702 & & & \\
\hline \multirow[t]{2}{*}{ Pleural indentation } & - & $82(20.9)$ & $32(25.2)$ & $50(18.8)$ & 1.00 & & & & & \\
\hline & + & $311(79.1)$ & $95(74.8)$ & $216(81.2)$ & 1.46 & $0.87-2.40$ & 0.1489 & & & \\
\hline \multirow[t]{2}{*}{ Spiculation } & - & $215(54.7)$ & $82(64.6)$ & $133(50.0)$ & 1.00 & & & & & \\
\hline & + & $178(45.3)$ & $45(35.4)$ & $133(50.0)$ & 1.82 & $1.18-2.83$ & 0.0063 & & & \\
\hline \multirow[t]{2}{*}{ Cavitation } & - & $320(81.4)$ & $110(86.6)$ & $210(79.0)$ & 1.00 & & & & & \\
\hline & + & 73 (18.6) & $17(13.4)$ & $56(21.0)$ & 1.73 & $0.97-3.19$ & 0.0615 & & & \\
\hline
\end{tabular}

GGO: Ground glass opacity, OR: odds ratio, CI: confidence interval.

Table III. Univariate and multivariate analysis of the relationship between programmed cell death-ligand 1 (PD-L1)/PD-L2 co-expression and computed tomographic features.

\begin{tabular}{|c|c|c|c|c|c|c|c|c|c|c|}
\hline \multirow[t]{2}{*}{ CT feature } & & \multirow[t]{2}{*}{$\mathrm{N}(\%)$} & \multicolumn{2}{|c|}{ PD-L1/PD-L2, N (\%) } & \multicolumn{3}{|c|}{ Univariate analysis } & \multicolumn{3}{|c|}{ Multivariate analysis } \\
\hline & & & Other ${ }^{\mathrm{a}}$ & Co-expression & OR & $95 \% \mathrm{CI}$ & $p$-Value & OR & $95 \% \mathrm{CI}$ & $p$-Value \\
\hline \multirow[t]{2}{*}{ Convergence } & - & $129(32.8)$ & $117(39.7)$ & $12(12.2)$ & 1.00 & & & 1.00 & & \\
\hline & + & $264(67.2)$ & $178(60.3)$ & $86(87.8)$ & 4.71 & $2.55-9.42$ & $<0.0001$ & 2.39 & $1.19-5.07$ & 0.0136 \\
\hline \multirow[t]{2}{*}{ Surrounding GGO } & - & 204 (51.9) & $128(43.4)$ & $76(77.6)$ & 1.00 & & & 1.00 & & \\
\hline & + & $189(48.1)$ & $167(56.6)$ & $22(22.4)$ & 0.22 & $0.13-0.37$ & $<0.0001$ & 0.34 & $0.19-0.59$ & 0.0001 \\
\hline \multirow[t]{2}{*}{ Air bronchogram } & - & $81(20.6)$ & $59(20.0)$ & $22(22.5)$ & 1.00 & & & & & \\
\hline & + & $312(79.4)$ & $236(80.0)$ & $76(77.6)$ & 0.86 & $0.50-1.53$ & 0.6061 & & & \\
\hline \multirow[t]{2}{*}{ Notching } & - & $251(63.9)$ & $202(68.5)$ & $49(50.0)$ & 1.00 & & & & & \\
\hline & + & $142(36.1)$ & $93(31.5)$ & $49(50.0)$ & 2.17 & $1.36-3.47$ & 0.0011 & & & \\
\hline \multirow[t]{2}{*}{ Pleural indentation } & - & $82(20.9)$ & $68(23.1)$ & $14(14.3)$ & 1.00 & & & & & \\
\hline & + & $311(79.1)$ & $227(76.9)$ & $84(85.7)$ & 1.80 & $0.98-3.48$ & 0.0563 & & & \\
\hline \multirow[t]{2}{*}{ Spiculation } & - & $215(54.7)$ & $178(60.3)$ & 37 (37.8) & 1.00 & & & & & \\
\hline & + & $178(45.3)$ & $117(39.7)$ & $61(62.2)$ & 2.51 & $1.57-4.04$ & $<0.0001$ & & & \\
\hline \multirow{2}{*}{ Cavitation } & - & $320(81.4)$ & $254(86.1)$ & $66(67.4)$ & 1.00 & & & 1.00 & & \\
\hline & + & 73 (18.6) & 41 (13.9) & $32(32.6)$ & 3.00 & $1.75-5.13$ & $<0.0001$ & 2.04 & $1.15-3.60$ & 0.0145 \\
\hline
\end{tabular}

GGO: Ground glass opacity, OR: odds ratio, CI: confidence interval. ${ }^{a}$ No expression or single protein expression.

previous study identified significant differences in FDG uptake across histological subtypes and differentiation groups of NSCLC, which paralleled differences in the Ki-67 index (37). Therefore, PD-L2-positive lung adenocarcinoma may harbor more proliferative traits than PD-L2-negative tumors. We recently found that PD-L1 positivity was an independent predictor of shorter disease-free survival, and that both PD-L1 and PD-L2 were predictors of shorter overall survival in 433 patients with primary lung adenocarcinoma (unpublished observations). Thus, PD-L2-positive lung adenocarcinoma was not as pathologically or radiologically invasive as PD-L1positive lung adenocarcinoma, but PD-L2 expression appears to be related to tumor malignancy in lung adenocarcinoma.

Some recent studies have suggested that PD-L2 expression may be related to the response to PD-1-targeted immunotherapy. For example, Yearley et al. showed that PD-L2 
A

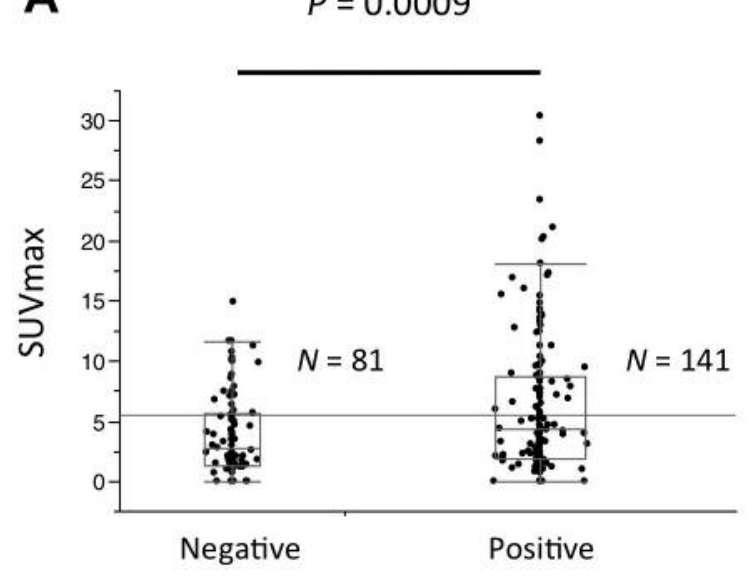

PD-L2
B

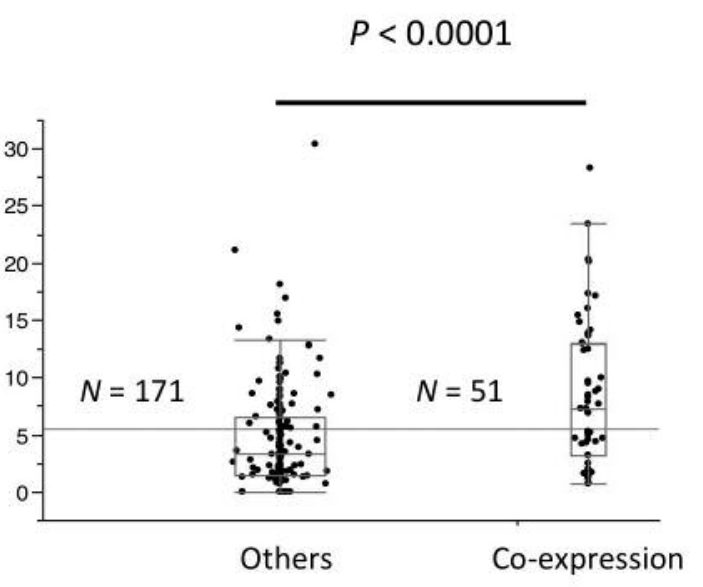

PD-L1/PD-L2

Figure 3. Maximum standardized uptake value $\left(S U V_{\max }\right)$ stratified by programmed cell death-ligand $1(P D-L 1)$ and PD-L2 expression. A: SUV $V_{\text {max }}$ was significantly higher in patients with PD-L2-positive compared with PD-L2-negative tumors $(p=0.0009)$. B: SUV max was significantly higher in patients with tumors co-expressing PD-L1 and PD-L2 compared to those expressing no or single protein $(p<0.0001)$.

expression was a significant predictor of progression-free and overall survival in patients with squamous cell carcinoma of the head and neck treated with the PD-1 inhibitor pembrolizumab (38). Although a similar relationship has not yet been established for PD-L2 expression, our data are likely to help clarify the clinical significance of PD-L2 expression in NSCLC.

There are several limitations to this study. Firstly, it was a single institutional retrospective study and not a trial-based correlative study; thus, the possibility of bias cannot be excluded. Validation cohort studies should be conducted to confirm our results. However, to our knowledge this is the first report to demonstrate the relationship between PD-L2 expression and features of imaging modalities in resected lung adenocarcinomas. Secondly, we conducted PD-L1 IHC using only one antibody. Several recent studies have shown that positive PD-L1 expression is detected at a lower rate with the SP142 antibody used here than with other antibodies, such as 28-8, 22C3, and SP263 (39-42). We should conduct the same analysis using these and other available PD-L1-specific antibodies. Thirdly, there are no definitive guidelines for antibody use or quantification of PD-L2 expression in NSCLC, and no comparative data are available for different PD-L2 antibodies. We used clone 176611 and set the cut-off value for positivity as membranous staining $1 \%$ of tumor cells in this study. However, this antibody has not been evaluated in a clinical setting. Therefore, PD-L2 expression should be further evaluated using other antibodies and cut-off values. The fourth limitation is the lack of analysis of only patients with advanced cancer such as stage IV, which was due to our focus being on resected lung adenocarcinoma. Further
Table IV. Frequency of programmed cell death-ligand 2 (PD-L2) expression according to the consolidation/tumor (C/T) ratio.

\begin{tabular}{lccc}
\hline C/T ratio & \multicolumn{2}{c}{ PD-L2, N (\%) } & \\
\cline { 2 - 3 } & Negative & Positive & $p$-Value \\
\hline 0 (pure GGO) & $17(13.4)$ & $22(8.3)$ & 0.3188 \\
$0.10-0.25$ & $5(3.9)$ & $16(6.0)$ & \\
$0.26-0.50$ & $18(14.2)$ & $32(12.0)$ & \\
$\geq 0.51$ & $87(68.5)$ & $196(73.7)$ & \\
\hline
\end{tabular}

GGO: Ground glass opacity.

Table V. Frequency of programmed cell death-ligand 1 (PD-L1)/PD-L2 co-expression according to the consolidation/tumor (C/T) ratio.

\begin{tabular}{lccc}
\hline C/T ratio & \multicolumn{2}{c}{ PD-L1/PD-L2, N (\%) } & \\
\cline { 2 - 3 } & Other & Co-expression & $p$-Value \\
\hline 0 (pure GGO) & $36(12.2)$ & $3(3.1)$ & 0.0006 \\
$0.10-0.25$ & $18(6.1)$ & $3(3.1)$ & \\
$0.26-0.50$ & $44(14.9)$ & $6(6.1)$ & \\
$\geq 0.51$ & $197(66.8)$ & $86(87.7)$ & \\
\hline
\end{tabular}

GGO: Ground glass opacity. aNo expression or single protein expression.

studies should include analysis of PD-L2 expression only in advanced lung adenocarcinoma specimens to validate our results here with resected tumors. 
Table VI. Association of programmed cell death-ligand 1 (PD-L1) and PD-L2 expression with clinicopathological factors.

\begin{tabular}{|c|c|c|c|c|c|c|c|c|c|c|}
\hline \multirow[b]{2}{*}{ Factor } & \multicolumn{4}{|c|}{ PD-L1, N (\%) } & \multicolumn{2}{|c|}{ PD-L2, N (\%) } & \multicolumn{4}{|c|}{ PD-L1/PD-L2, N (\%) } \\
\hline & $\mathrm{N}(\%)$ & Negative & Positive & $p$-Value & Negative & Positive & $p$-Value & Co-expression & Other ${ }^{b}$ & $p$-Value \\
\hline \multicolumn{11}{|l|}{ Age } \\
\hline$<70$ Years & $207(52.7)$ & $136(52.1)$ & $71(53.8)$ & 0.8307 & $65(51.2)$ & $142(53.4)$ & 0.7460 & $51(52.0)$ & $156(52.9)$ & 0.9074 \\
\hline$\geq 70$ Years & $186(47.3)$ & $125(47.9)$ & $61(46.2)$ & & $62(48.8)$ & $124(46.6)$ & & $47(48.0)$ & $139(47.1)$ & \\
\hline \multicolumn{11}{|l|}{ Gender } \\
\hline Male & $196(49.9)$ & $117(44.8)$ & 79 (59.9) & 0.0055 & $74(58.3)$ & $122(45.9)$ & 0.0237 & $51(52.0)$ & $145(49.1)$ & 0.6423 \\
\hline Female & $197(50.1)$ & $144(55.2)$ & $53(40.1)$ & & $53(41.7)$ & $144(54.1)$ & & $47(48.0)$ & $150(50.9)$ & \\
\hline \multicolumn{11}{|l|}{ Smoking status } \\
\hline Never-smoker & $201(51.2)$ & $149(57.1)$ & $52(39.4)$ & 0.0010 & $52(40.9)$ & $149(56.0)$ & 0.0069 & $48(49.0)$ & $153(51.9)$ & 0.6422 \\
\hline Smoker & $192(48.8)$ & $112(42.9)$ & $80(60.6)$ & & $75(59.1)$ & $117(44.0)$ & & $50(51.0)$ & $142(48.1)$ & \\
\hline \multicolumn{11}{|l|}{ Radiologic tumor diameter } \\
\hline$\leq 2.0 \mathrm{~cm}$ & $180(45.8)$ & $127(48.7)$ & $53(40.2)$ & 0.1333 & $79(62.2)$ & $101(38.0)$ & $<0.0001$ & 33 (33.7) & $147(49.8)$ & 0.0069 \\
\hline$>2.0 \mathrm{~cm}$ & $213(54.2)$ & $134(51.3)$ & $79(59.8)$ & & $48(37.8)$ & $165(62.0)$ & & $65(66.3)$ & $148(50.2)$ & \\
\hline \multicolumn{11}{|l|}{ Pathological stage } \\
\hline I & $286(72.8)$ & $204(78.2)$ & $82(62.1)$ & 0.0011 & $103(81.1)$ & $183(68.8)$ & 0.0109 & $58(59.2)$ & $228(77.3)$ & 0.0010 \\
\hline$\geq \mathrm{II}$ & $107(27.2)$ & $57(21.8)$ & $50(37.9)$ & & $24(18.9)$ & $83(31.2)$ & & $40(40.8)$ & $67(22.7)$ & \\
\hline \multicolumn{11}{|l|}{ Pleural invasion ${ }^{\mathrm{a}}$} \\
\hline No & $305(77.8)$ & $215(82.7)$ & $90(68.2)$ & 0.0019 & $104(82.5)$ & $201(75.6)$ & 0.1520 & 67 (68.4) & $238(81.0)$ & 0.0116 \\
\hline Yes & $87(22.2)$ & $45(17.3)$ & $42(31.8)$ & & $22(17.5)$ & $65(24.4)$ & & $31(31.6)$ & $56(19.0)$ & \\
\hline \multicolumn{11}{|l|}{ Lymphatic invasion } \\
\hline No & $337(85.8)$ & $223(85.4)$ & $114(86.4)$ & 0.8792 & $116(91.3)$ & $221(83.1)$ & 0.0308 & $81(82.7)$ & $256(86.8)$ & 0.3195 \\
\hline Yes & $56(14.2)$ & $38(14.6)$ & $18(13.6)$ & & $11(8.7)$ & $45(16.9)$ & & $17(17.3)$ & $39(13.2)$ & \\
\hline \multicolumn{11}{|l|}{ Vascular invasion } \\
\hline No & $279(71.0)$ & $206(78.9)$ & $73(55.3)$ & $<0.0001$ & 96 (75.6) & $183(68.8)$ & 0.1914 & $55(56.1)$ & $224(75.9)$ & 0.0003 \\
\hline Yes & $114(29.0)$ & $55(21.1)$ & $59(44.7)$ & & $31(24.4)$ & $83(31.2)$ & & $43(43.9)$ & $71(24.1)$ & \\
\hline \multicolumn{11}{|l|}{ Histological subtype } \\
\hline AAH/AIS/MIA/lepidic & $63(16.0)$ & $57(21.8)$ & $6(4.6)$ & $<0.0001$ & $32(25.2)$ & $31(11.7)$ & 0.0011 & $5(5.1)$ & $58(19.7)$ & 0.0004 \\
\hline Other & $330(84.0)$ & $204(78.2)$ & $126(95.4)$ & & $95(74.8)$ & $235(88.3)$ & & $93(94.9)$ & $237(80.3)$ & \\
\hline \multicolumn{11}{|l|}{$E G F R^{a}$} \\
\hline Wild-type & $119(51.7)$ & $79(46.5)$ & $40(66.7)$ & 0.0103 & $46(54.8)$ & $73(50.0)$ & 0.4969 & $29(65.9)$ & $90(48.4)$ & 0.0441 \\
\hline Mutant & $111(48.3)$ & $91(53.5)$ & $20(33.3)$ & & $38(45.2)$ & $73(50.0)$ & & $15(34.1)$ & $96(51.6)$ & \\
\hline
\end{tabular}

EGFR: Epidermal growth factor receptor, AAH: atypical adenomatous hyperplasia, AIS: adenocarcinoma in situ, MIA: minimally-invasive

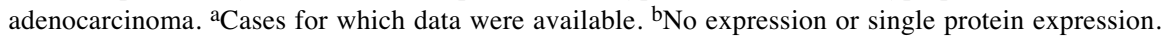

To the best of our knowledge, this is the first report of a relationship between PD-L2 expression and radiological and metabolic imaging features in lung adenocarcinoma. PD-L2positive lung adenocarcinoma was less radiologically malignant and invasive compared to PD-L1-positive tumors. Further studies are warranted to provide more detailed information about the clinical features of PD-L2-positive NSCLC, including squamous cell carcinoma.

\section{Funding Statement}

This work was not supported by any funding sources.

\section{Conflicts of Interest}

The Authors have declared no conflicts of interest in regard to this study.

\section{Acknowledgements}

The Authors thank Edanz Group (www.edanzediting.com/ac) for editing a draft of this manuscript. We are also grateful to biostatistician, Mototsugu Shimokawa (Clinical Research Institute, National Kyushu Cancer Center, Fukuoka, Japan), for helpful comments about statistical analysis.

\section{References}

1 Rittmeyer A, Barlesi F, Waterkamp D, Park K, Ciardiello F, von Pawel J, Gadgeel SM, Hida T, Kowalski DM, Dols MC, Cortinovis DL, Leach J, Polikoff J, Barrios C, Kabbinavar F, Frontera OA, De Marinis F, Turna H, Lee JS, Ballinger M, Kowanetz M, He P, Chen DS, Sandler A and Gandara DR: Atezolizumab versus docetaxel in patients with previously treated non-small-cell lung cancer (OAK): A phase 3, open-label, multicentre randomised controlled trial. Lancet 389: 255-265, 2017. 
2 Reck M, Rodriguez-Abreu D and Robinson AG, Hui R, Csoszi T, Fulop A, Gottfried M, Peled N, Tafreshi A, Cuffe S, O'Brien M, Rao S, Hotta K, Leiby MA, Lubiniecki GM, Shentu Y, Rangwala $\mathrm{R}$ and Brahmer JR: Pembrolizumab versus chemotherapy for PD-L1-positive non-small-cell lung cancer. N Engl J Med 375: 1823-1833, 2016.

3 Herbst RS, Baas P, Kim DW, Felip E, Perez-Gracia JL and Han JY, Molina J, Kim JH, Arvis CD, Ahn MJ, Majem M, Fidler MJ, de Castro G, Garrido M, Lubiniecki GM, Shentu Y, Im E, Dolled-Filhart $\mathrm{M}$ and Garon EB: Pembrolizumab versus docetaxel for previously treated, PD-L1-positive, advanced nonsmall-cell lung cancer (KEYNOTE-010): A randomised controlled trial. Lancet 387: 1540-1550, 2016.

4 Fehrenbacher L, Spira A, Ballinger M, Kowanetz M, Vansteenkiste J, Mazieres J, Park K, Smith D, Artal-Cortes A, Lewanski C, Braiteh F, Waterkamp D, He P, Zou W, Chen DS, Yi J, Sandler A and Rittmeyer A: Atezolizumab versus docetaxel for patients with previously treated non-small-cell lung cancer (POPLAR): A multicentre, open-label, phase 2 randomised controlled trial. Lancet 387: 1837-1846, 2016.

5 Brahmer J, Reckamp KL, Baas P, Crino L, Eberhardt WE, Poddubskaya E, Antonia S, Pluzanski A, Vokes EE, Holgado E, Waterhouse D, Ready N, Gainor J, Aren Frontera O, Havel L, Steins M, Garassino MC, Aerts JG, Domine M, Paz-Ares L, Reck M, Baudelet C, Harbison CT, Lestini B and Spigel DR: Nivolumab versus docetaxel in advanced squamous-cell nonsmall-cell lung cancer. N Engl J Med 373: 123-135, 2015.

6 Borghaei H, Paz-Ares L and Horn L, Spigel DR, Steins M, Ready NE, Chow LQ, Vokes EE, Felip E, Holgado E, Barlesi F, Kohlhaufl M, Arrieta O, Burgio MA, Fayette J, Lena H, Poddubskaya E, Gerber DE, Gettinger SN, Rudin CM, Rizvi N, Crino L, Blumenschein GR Jr., Antonia SJ, Dorange C, Harbison $\mathrm{CT}$, Graf Finckenstein F and Brahmer JR: Nivolumab versus docetaxel in advanced nonsquamous non-small-cell lung cancer. N Engl J Med 373: 1627-1639, 2015.

7 Sacher AG and Gandhi L: Biomarkers for the clinical use of PD1/PD-L1 inhibitors in non-small-cell lung cancer: A review. JAMA Oncol 2: 1217-1222, 2016.

8 Carbognin L, Pilotto S, Milella M, Vaccaro V, Brunelli M, Calio A, Cuppone F, Sperduti I, Giannarelli D, Chilosi M, Bronte V, Scarpa A, Bria E and Tortora G: Differential activity of nivolumab, pembrolizumab and MPDL3280A according to the tumor expression of programmed death-ligand-1 (PD-L1): Sensitivity analysis of trials in melanoma, lung and genitourinary cancers. PLoS One 10: e0130142, 2015.

9 Latchman Y, Wood CR, Chernova T, Chaudhary D, Borde M, Chernova I, Iwai Y, Long AJ, Brown JA, Nunes R, Greenfield EA, Bourque K, Boussiotis VA, Carter LL, Carreno BM, Malenkovich N, Nishimura H, Okazaki T, Honjo T, Sharpe AH and Freeman GJ: PD-L2 is a second ligand for PD-1 and inhibits T-cell activation. Nat Immunol 2: 261-268, 2001.

10 Youngnak P, Kozono Y, Kozono H, Iwai H, Otsuki N, Jin H, Omura K, Yagita H, Pardoll DM, Chen L and Azuma M: Differential binding properties of B7-H1 and B7-DC to programmed death-1. Biochem Biophys Res Commun 307: 672677, 2003.

11 Koh J, Go H, Keam B, Kim MY, Nam SJ, Kim TM, Lee SH, Min HS, Kim YT, Kim DW, Jeon YK and Chung DH: Clinicopathologic analysis of programmed cell death-1 and programmed cell death-ligand 1 and 2 expressions in pulmonary adenocarcinoma: comparison with histology and driver oncogenic alteration status. Mod Pathol 28: 1154-1166, 2015.

$12 \mathrm{Kim}$ MY, Koh J, Kim S, Go H, Jeon YK and Chung DH: Clinicopathological analysis of PD-L1 and PD-L2 expression in pulmonary squamous cell carcinoma: Comparison with tumorinfiltrating T-cells and the status of oncogenic drivers. Lung Cancer 88: 24-33, 2015.

13 Calles A, Liao X, Sholl LM, Rodig SJ, Freeman GJ, Butaney M, Lydon C, Dahlberg SE, Hodi FS, Oxnard GR, Jackman DM and Janne PA: Expression of PD-1 and its ligands, PD-L1 and PDL2, in smokers and never smokers with KRAS-mutant lung cancer. J Thorac Oncol 10: 1726-1735, 2015.

14 Zhang Y, Wang L, Li Y, Pan Y, Wang R, Hu H, Li H, Luo X, Ye $\mathrm{T}$, Sun $\mathrm{Y}$ and Chen H: Protein expression of programmed death 1 ligand 1 and ligand 2 independently predict poor prognosis in surgically resected lung adenocarcinoma. Onco Targets Ther 7: 567-573, 2014.

15 Konishi J, Yamazaki K, Azuma M, Kinoshita I, Dosaka-Akita H and Nishimura M: B7-H1 expression on non-small cell lung cancer cells and its relationship with tumor-infiltrating lymphocytes and their PD-1 expression. Clin Cancer Res 10: 5094-5100, 2004.

16 Toyokawa G, Takada K, Okamoto T, Shimokawa M, Kozuma Y, Matsubara T, Haratake N, Takamori S, Akamine T, Katsura M, Shoji F, Oda Y and Maehara Y: Computed tomography features of lung adenocarcinomas with programmed death ligand 1 expression. Clin Lung Cancer 18: e375-e383, 2017.

17 Takada K, Toyokawa G, Tagawa T, Kohashi K, Akamine T, Takamori S, Hirai F, Shoji F, Okamoto T, Oda Y and Maehara Y: Association between PD-L1 expression and metabolic activity on (18)F-FDG PET/CT in patients with small-sized lung cancer. Anticancer Res 37: 7073-7082, 2017.

18 Takada K, Toyokawa G, Okamoto T, Baba S, Kozuma Y, Matsubara T, Haratake N, Akamine T, Takamori S, Katsura M, Shoji F, Honda H, Oda Y and Maehara Y: Metabolic characteristics of programmed cell death-ligand 1-expressing lung cancer on ${ }^{18} \mathrm{~F}$ fluorodeoxyglucose positron-emission tomography/computed tomography. Cancer Med 6: 2552-2561, 2017.

19 Goldstraw P, Crowley J, Chansky K, Giroux DJ, Groome PA, Rami-Porta R and Postmus PE, Rusch V and Sobin L: The IASLC Lung Cancer Staging Project: proposals for the revision of the TNM stage groupings in the forthcoming (seventh) edition of the TNM Classification of Malignant Tumours. J Thorac Oncol 2: 706-714, 2007.

20 Travis WD, Brambilla E, Nicholson AG, Yatabe Y, Austin JHM, Beasley MB, Chirieac LR, Dacic S, Duhig E, Flieder DB, Geisinger K, Hirsch FR, Ishikawa Y, Kerr KM, Noguchi M, Pelosi G, Powell CA, Tsao MS and Wistuba I: The 2015 World Health Organization Classification of Lung Tumors: Impact of genetic, clinical and radiologic advances since the 2004 classification. J Thorac Oncol 10: 1243-1260, 2015.

21 Kohno M, Okamoto T, Suda K, Shimokawa M, Kitahara H, Shimamatsu S, Konishi H, Yoshida T, Takenoyama M, Yano T and Maehara Y: Prognostic and therapeutic implications of aromatase expression in lung adenocarcinomas with EGFR mutations. Clin Cancer Res 20: 3613-3622, 2014.

22 Toyokawa G, Takada K, Okamoto T, Kozuma Y, Matsubara T, Haratake N, Takamori S, Akamine T, Katsura M, Shoji F, Oda $\mathrm{Y}$ and Maehara Y: High frequency of programmed death-ligand 1 expression in emphysematous bullae-associated lung adenocarcinomas. Clin Lung Cancer 18: 504-511, 2017. 
23 Toyokawa G, Takada K, Okamoto T, Kawanami S, Kozuma Y, Matsubara T, Haratake N, Takamori S, Akamine T, Katsura M, Yamada Y, Shoji F, Baba S, Kamitani T, Oda Y, Honda H and Maehara Y: Relevance between programmed death ligand 1 and radiologic invasiveness in pathologic stage I lung adenocarcinoma. Ann Thorac Surg 103: 1750-1757, 2017.

24 Takamori S, Toyokawa G, Okamoto I, Takada K, Kozuma Y, Matsubara T, Haratake N, Akamine T, Katsura M, Mukae N, Shoji F, Okamoto T, Oda Y, Iwaki T, Iihara K, Nakanishi Y and Maehara Y: Discrepancy in programmed cell death-ligand 1 between primary and metastatic non-small cell lung cancer. Anticancer Res 37: 4223-4228, 2017.

25 Takada K, Toyokawa G, Okamoto T, Shimokawa M, Kozuma Y, Matsubara T, Haratake N, Akamine T, Takamori S, Katsura M, Shoji F, Oda Y and Maehara Y: A Comprehensive Analysis of programmed cell death ligand-1 expression with the clone SP142 antibody in non-small-cell lung cancer patients. Clin Lung Cancer 18: 572-582, 2017.

26 Takada K, Okamoto T, Toyokawa G, Kozuma Y, Matsubara T, Haratake N, Akamine T, Takamori S, Katsura M, Shoji F, Oda $\mathrm{Y}$ and Maehara Y: The expression of PD-L1 protein as a prognostic factor in lung squamous cell carcinoma. Lung Cancer 104: 7-15, 2017.

27 Takada K, Okamoto T, Tominaga M, Teraishi K, Akamine T, Takamori S, Katsura M, Toyokawa G, Shoji F, Okamoto M, Oda Y, Hoshino T and Maehara Y: Clinical implications of the novel cytokine IL-38 expressed in lung adenocarcinoma: Possible association with PD-L1 expression. PLoS One 12: e0181598, 2017.

28 Haratake N, Toyokawa G, Takada K, Kozuma Y, Matsubara T, Takamori S, Akamine T, Katsura M, Shoji F, Okamoto T, Oda Y and Maehara Y: Programmed death-ligand 1 expression and EGFR mutations in multifocal lung cancer. Ann Thorac Surg 105: 448-454, 2018.

29 Toyokawa G, Takada K, Haratake N, Takamori S, Akamine T, Katsura M, Fujishita T, Shoji F, Okamoto T, Oda Y and Maehara Y: Favorable disease-free survival associated with programmed death ligand 1 expression in patients with surgically resected small-cell lung cancer. Anticancer Res 36: 4329-4336, 2016.

30 Takada K, Toyokawa G, Okamoto T, Akamine T, Takamori S, Katsura M, Fujishita T, Shoji F, Oda Y and Maehara Y: An Immunohistochemical analysis of PD-L1 protein expression in surgically resected small cell lung cancer using different antibodies and criteria. Anticancer Res 36: 3409-3412, 2016.

31 Takada K, Okamoto T, Shoji F, Shimokawa M, Akamine T, Takamori S, Katsura M, Suzuki Y, Fujishita T, Toyokawa G, Morodomi Y, Okano S, Oda Y and Maehara Y: Clinical significance of PD-L1 protein expression in surgically resected primary lung adenocarcinoma. J Thorac Oncol 11: 1879-1890, 2016.

32 Hattori A, Suzuki K, Maeyashiki T, Fukui M, Kitamura Y, Matsunaga T, Miyasaka Y, Takamochi K and Oh S: The presence of air bronchogram is a novel predictor of negative nodal involvement in radiologically pure-solid lung cancer. Eur J Cardiothorac Surg 45: 699-702, 2014.

33 Maeyashiki T, Suzuki K, Hattori A, Matsunaga T, Takamochi K and Oh S: The size of consolidation on thin-section computed tomography is a better predictor of survival than the maximum tumour dimension in resectable lung cancer. Eur J Cardiothorac Surg 43: 915-918, 2013.
34 Hattori A, Suzuki K, Matsunaga T, Fukui M, Kitamura Y, Miyasaka Y, Tsushima Y, Takamochi K and Oh S: Is limited resection appropriate for radiologically "solid" tumors in small lung cancers? Ann Thorac Surg 94: 212-215, 2012.

35 Yoshino I, Ichinose Y, Nagashima A, Takeo S, Motohiro A, Yano T, Yokoyama H, Ueda H, Sugio K, Ishida T, Yasumoto K and Maehara Y: Clinical characterization of node-negative lung adenocarcinoma: Results of a prospective investigation. J Thorac Oncol 1: 825-831, 2006.

36 Suzuki K, Koike T, Asakawa T, Kusumoto M, Asamura H, Nagai K, Tada H, Mitsudomi T, Tsuboi M, Shibata T, Fukuda H and Kato $\mathrm{H}$ : A prospective radiological study of thin-section computed tomography to predict pathological noninvasiveness in peripheral clinical IA lung cancer (Japan Clinical Oncology Group 0201). J Thorac Oncol 6: 751-756, 2011.

37 Vesselle H, Salskov A, Turcotte E, Wiens L, Schmidt R, Jordan $\mathrm{CD}$, Vallieres $\mathrm{E}$ and Wood DE: Relationship between non-small cell lung cancer FDG uptake at PET, tumor histology, and Ki67 proliferation index. J Thorac Oncol 3: 971-978, 2008.

38 Yearley JH, Gibson C, Yu N, Moon C, Murphy E, Juco J, Lunceford J, Cheng J, Chow LQM, Seiwert TY, Handa M, Tomassini JE and McClanahan T: PD-L2 expression in human tumors: relevance to anti-PD-1 therapy in cancer. Clin Cancer Res 23: 3158-3167, 2017.

39 Rimm DL, Han G, Taube JM, Yi ES, Bridge JA, Flieder DB, Homer R, West WW, Wu H, Roden AC, Fujimoto J, Yu H, Anders R, Kowalewski A, Rivard C, Rehman J, Batenchuk C, Burns V, Hirsch FR, Wistuba, II: A Prospective, multiinstitutional, pathologist-based assessment of 4 immunohistochemistry assays for PD-L1 expression in nonsmall cell lung cancer. JAMA Oncol 3: 1051-1058, 2017.

40 Ratcliffe MJ, Sharpe A, Midha A, Barker C, Scott M, Scorer P, Al-Masri $\mathrm{H}$ and Rebelatto $\mathrm{MC}$ and Walker J: Agreement between programmed cell death ligand-1 diagnostic assays across multiple protein expression cutoffs in non-small cell lung cancer. Clin Cancer Res 23: 3585-3591, 2017.

41 Hirsch FR, McElhinny A, Stanforth D, Ranger-Moore J and Jansson M, Kulangara K, Richardson W, Towne P, Hanks D, Vennapusa B, Mistry A, Kalamegham R, Averbuch S, Novotny J, Rubin E, Emancipator K, McCaffery I, Williams JA, Walker J, Longshore J, Tsao MS and Kerr KM: PD-L1 Immunohistochemistry assays for lung cancer: Results from phase 1 of the Blueprint PD-L1 IHC assay comparison project. J Thorac Oncol 12: 208-222, 2017

42 Scheel AH, Dietel M, Heukamp LC, Johrens K, Kirchner T, Reu S, Ruschoff J, Schildhaus HU, Schirmacher P, Tiemann M, Warth A, Weichert W, Fischer RN, Wolf $\mathrm{J}$ and Buettner R: Harmonized PD-L1 immunohistochemistry for pulmonary squamous-cell and adenocarcinomas. Mod Pathol 29: 1165-1172, 2016.
Received August 15, 2018

Revised September 12, 2018 Accepted September 19, 2018 